\title{
The Correlation of Event Tourism towards Travel Motivation and Its Impact on Destination Image of Bali
}

\author{
Komang Trisna Pratiwi Arcana \\ Tourism Management Program, The International Bali Tourism Institute (STPBI) \\ trisnapratiwi.arcana@gmail.com
}

\begin{abstract}
The implementation of Event Tourism is one form of promotion of a destination that combines a variety of products and displayed in the form of festivals, special events, Meeting, Incentive, Convention, and Exhibition Tourism (MICE Tourism) with the aim of providing a personal experience at a destination. Bali that had degraded its destinations image after terrorist attacks in 2002 and 2005 has made various efforts to restore the image by organizing tourism events. Tourism Image Destinations is an essential component in selecting decision by tourists about travel destinations. This research was focusing on the study of the relationship of organizing event tourism in Bali toward tourist motivation. The study was done to 50 respondents during the silent day in Bali in 2016. By using association correlation test or Chi-Square $\left(X^{2}\right)$, which was analyzed using the Statistical Package for Social Science (SPSS) version 23 showed that there was a positive correlation of the implementation of tourism event toward travel motivation and its impact in establishing the destination image of Bali Island itself. Pearson ChiSquare line showed the price of $p$-value was $0.000<0.05$ or Ho was rejected. So that through this study, Bali local government must continue to improve creativity in encouraging the growth of Event Tourism for the realization of destination image which safe, peaceful, and superior because of its cultural attractions, natural or man-made art. The local government is also expected to pay particular attention to the potential of this special interest market.
\end{abstract}

Keywords: Event Tourism; Travel Motivation; Destination Image; Bali 


\section{Introduction}

In the $19^{\text {th }}$ century, the engine of employment is agriculture sector, while in the $20^{\text {th }}$ century is the manufacturing industry, and in the $21^{\text {st }}$ century is the tourism industry. Even since 1950, the tourism industry had become one of the driving sectors of the economy of a country (Cooper, 2012: 5). As an industry that contributes the source of occupations, local revenue, and foreign exchange, tourism is not only reaching out the tourism travel field, but also offers hospitality, as well as a product that is both tangible and intangible. This sector had proved to be able to move the chain of intertwined economies for a country that became a destination of world tourism and a development priority for developing countries (Emanuel de Kadt, 1979 in Sunaryo, 2013; Sunaryo, 2013: $33)$.

The tourism existence is proved by the growth of the tourism industry and travel activities that occur in various parts of the world. According to the United Nations World Tourism Organization (UNWTO), World Tourism Barometer (2016) the growth of tourist arrivals reached 4.4\% with total tourism revenue reached 1,184 million dollars in 2015. The growth in tourist arrivals data showed that demand on the tourism industry is still strong, even though there were several crises those impacts on the decline in the rate of international tourist arrivals. Some of the historic events occurred in parts of the world such as terrorist attacks " $9 / 11$ " that hit the skyscrapers of the World Trade Centre, bombs in tourist destinations of Kuta, Bali, the threat of avian influenza, the second Iraq war, bombing that occurred on the system trains in London and Madrid, the Tsunami in 2004, the economic crisis that occurred in 2008/2009 which destabilize the world economy, some terrorist attacks that terrorized the peace of the world in Paris in November 2015 and Jakarta in January 2016 (Page and Connell, 2009; Cooper, 2012; and Tribe, 2010). Those historic events had changed the behavior of tourists and tourist travel patterns world.

The crisis had struck various parts of the world and had an impact on economic stability, peace, and behavior patterns of tourists making tours. Those phenomenon demand a tourist destination to improve its competitiveness with its own uniqueness in order to remain sustainable. Bali as one of the leading 
destinations in the world has contributed to boosting the economy of Indonesia through the tourism sector. The tourism industry had become the main income for the people of Bali (Hara, 2008: 11). However, the credibility and image as a tourist destination which is beautiful, cultured, and secure were immediately destroyed by terrorist attacks in 2002 and 2005. The decline in the number of tourist arrivals amounted to 5.23\% (Bali Provincial Tourism Office, 2005). The tourism industry faced many challenges, especially in restoring the confidence of tourists to feel safe coming back to Bali. One of the efforts being made to restore the negative image of the destination was the implementation of national and international events. Nevertheless it would take several years to restore the image of Bali tourism as usual, and terror is still looming Bali tourism.

The implementation of Event Tourism is one form of promotion of a destination that combines a variety of products and displayed in the form of festivals, special events, Meeting, Incentive, Convention, and Exhibition Tourism (MICE Tourism) with the aim of providing a personal experience at a destination (Kartajaya and Nirwandar, 2013: 71). After several terrorist attacks in 2002 and 2005 in Bali, the government made some recovery steps for tourism destination through the event, such as Miss China Peagant; International Jazz Festival and the Three Diva at the Garuda Wisnu Kencana; Kuta Carnival, Nusa Dua Fiesta, Bali Arts Festival (which became a regular event and always offers a unique theme every year), following international exhibitions such as ITB Berlin; WTM London, JATA Japan, following the national exhibitions like Batam Expo, Majapahit Travel Fair Surabaya (Purnamasari, 2014: 359). It is important to know how far the influence of the organization of the event tourism of tourist motivation and its impact on the destination image of Bali, which had slumped after the bombing.

\section{Literature Review}

According to Getz (2007), the event is one of the motivators in the tourism industry and become one of the marketing plans of a destination that is important. The role of organizing the event is to give additional value and competitiveness of destinations. Event Tourism used by tourism organizations to promote the growth 
of the tourism market and become one of the strategies in promoting the destination and offers a unique and personal experience for tourists (Page and Connell, 2009). The term "Event Tourism" itself was just starting to emerge with marked emergence Journal Event Management at the end of 1980 and becoming a milestone in the evolution of the study of tourism in particular (Getz, 2002, 2007 in Page and Cornell 2009). The report from The New Zealand Tourist and Publicity Department (1987) also became one stake in establishing the studies of tourism event where it is stated that "Event Tourism is an important and rapidly growing segment of international tourism" (Getz and Page, 2015). The framework of Tourism Event then began compiled by Getz in 1986 (Getz and Page, 2015).

The growth of Event Tourism occurs because it is believed to be one of the important indicators in developing and shaping a positive destination image and the attractiveness of the market destination for tourist who are interested specifically in the special event (Page and Connell, 2009; Kotler et al, 2014). One of the advantages of the Tourism Event implementation is the double impact (multiplier effect) generated in the economy of a destination (Bond, 2008). Furthermore, Event Tourism can be defined as a systematic planning, developing and marketing of natural and artificial attractions in the activities of the establishment image and one marketing tool of destination marketing (Ritchie, 1997; Getz, 2008; Celik and Cetinkaya, 2013). Event Tourism plays an important role as framing a component of tourism demand and supply in its form as one kind of special interest tourism. Special interest, in this case, is the "experience" of tourists who are motivated by the special appeal of Event Tourism (Getz and Page, 2015). Tourist motivation is regarded as a combination of needs and wants that influence the tendency for travel in general, while Baloglu (2001) argues that the motivation affects the effective components of the image, or the feelings aroused by a place or a person who can assess a destination based on various travel motives (Vinh, 2013).

A study of some of the events that took place at the destination and its impact on local communities conducted by C. Chen (2011) by using factor analysis and cluster to obtain three clusters in the local community. Yingzhi, Xiaoming and Liu (2013) investigated the traveler's perspective by using a survey 
about "a case study of the tourist's perceived motivation and impacts of sport tourism event". The purpose of the study was to determine the frequency of tourist participation and motivation to evaluate their perceptions toward the organization of the Asian Winter Games in 2011.The questionnaire was created based on the opinions of The Asian Winter Games visitors in January and February 2011. While the data were analyzed by using Statistical Package for Social Science (SPSS) including descriptive analysis, chi-square, factor analysis, and structural equation modeling (SEM). While Chen and Mo (2014) in a study about "a survey of push and pull motivations of green event tourist" trying to explain one of the motivations of travel is to visit a green event. The study tried to give an understanding that the custom of tourists to visit the green event comes from internal and external factors (push and pull factor), and at the same time, the decision was influenced by the attributes of a tourist destination. The survey was conducted to collect data which are compiled from a questionnaire that consisting of push and pull factors and then analyzed by using chi-square and factor analysis.

Destinations image is an important indicator in travel decisions. It has been studied in vary of contexts by several researchers since the 1970s (Hunt, 1975; Lawson and Baud-Bovy, 1977; Crompton, 1979; Stringer, 1984; Dichter, 1985; Phelps, 1986; Frigden, 1987; Ahmed, 1991; Gartner, 1993; Kotler, 1994; Baloglo and McLeary, 1999; and Tapachai and Waryszak, 2000) in Pearce (2005) and Arcana (2014). The word "image" itself consists of two main components, namely functional and emotional (Kennedy, 1977 at the LeBlanc and Nguyen, 1996). The functional component consists of tangible characters which are easily measured by tourists, while the emotional characteristics associated with travelers' psychological dimensions that influence the feelings and attitudes towards the destination. Further Milman and Pizam (1995) explained three essential formation components of the destination image, such as product (cultural attractions, natural and artificial, price); attitude and ethics of tourism players when they interact; and environment (weather, scenery, quality of the facilities). Even a model of the formation of the destination image is also increasingly being developed by Baloglu and McCleary (1999) within the framework for analyzing Travel Destinations Image are divided into two main elements, namely the 
stimulus factors and personal factors. As a result, three indicators travel destination image according to Baloglu and McCleary (1999) is the motivation to travel, socio-demographic factors, and resources. The attributes of the destination image further assist the tourist in determining their favorite destinations.

\section{Methodology}

This research was conducted by using a quantitative approach, which is positivism and post-positivism concept (Jennings, 2001: 228; Sugiyono, 2014). The issues that examined in this study are the correlation of the Event Tourism to travel motivation and its impact on the destination image. Preliminary hypothesis is that there is $\mathrm{H} 1$ as a positive correlation of the implementation of the Event Tourism of the tourist motivation to travel in, and contribute to the establishment of tourism destination image; and Ho means no relation of the implementation of tourism event of the tourist motivation and its impact on the formation of destination image. The Preliminary hypothesis in this research will be verified by doing Chi-Square association relationship test or Kai -Square $\left(\mathrm{X}^{2}\right)$. According to Kadir (2015), Chi-Square technique is used to test hypotheses about the relationship between two variables, where one or both variable is sized nominal.

The data collection was done by distributing 50 questionnaires to tourists who come to Bali for enjoying the Silent Day in March 2016, and stay at some tourist destinations like Kuta, Jimbaran, Seminyak, Ubud and Sanur. The respondents were tourists which are a group of MJ Travel and Event period 8 to 11 March 2016. Respondents were chosen by using purposive sampling with data collection conducted in the primary. The questionnaire was collected directly by the tour leader on the last day of the trip. To maintain the validity of the data, the questionnaire is checked first before being collected to make sure all questions were answered by the respondents.

Data analysis tool in this study was using the Statistical Package for Social Science (SPSS) version 23 including the descriptive analysis to test the association relationship. The data was analyzed through several stages such as editing and coding which were useful to simplify the researchers in analyzing and 
accelerating the process of data entry. The research variables were divided into interdependent variables $(\mathrm{X})$, dependent $(\mathrm{Y})$, and the intervening variables $(\mathrm{Z})$. The significance test will be analyzed by using SPSS version 23 with an alpha value of $5 \%(0.05)$ and the p-value, as the value of the magnitude of the opportunity to determine the results of research testing decision statistic. The hypothesis to be tested from this study will be included with the following conditions Kadir (2015); Putri (2008):

1. If the p-value >0.05 indicates that there is no significant relationship between the dependent and independent variables.

2. If the $\mathrm{p}$-value $<0.05$ indicates that there is a significant relationship between the dependent and independent variables

The results of Chi-Square test will conclude whether there is a proportion between groups or only able to conclude whether or not a relationship between two or more categorical variables.

\section{Results}

Table 1

\section{Socio Demographic Characteristics of Respondent}

\begin{tabular}{|l|l|l|}
\hline Characteristic & Percentage \\
\hline Nationality & $(n=50)$ & \\
\cline { 2 - 3 } & Domestic & 30.9 \\
\cline { 2 - 3 } & Europe & 14.4 \\
\cline { 2 - 3 } & Australia & 26.8 \\
\cline { 2 - 3 } & America & 12.2 \\
\cline { 2 - 3 } & Asia & 15.7 \\
\hline Gender & $(n=50)$ & 47.9 \\
\cline { 2 - 3 } & Male & 52.1 \\
\cline { 2 - 3 } & Female & \\
\hline Education & $(n=50)$ & 20.4 \\
\cline { 2 - 3 } & High School or less & \\
\hline
\end{tabular}




\begin{tabular}{|l|l|l|}
\multirow{4}{*}{ Occupation Level } & Graduate & 49.6 \\
\cline { 2 - 3 } & Post Graduate & 30 \\
\cline { 2 - 3 } & Employee & \\
\cline { 2 - 3 } & Supervisor & 39.7 \\
\cline { 2 - 3 } & $\begin{array}{l}\text { Manager } \\
\text { Director }\end{array}$ & 34.7 \\
\hline Marital Status & $(n=50)$ & \\
\cline { 2 - 3 } & Single & 57.7 \\
\cline { 2 - 3 } & Married & 42.3 \\
\hline Total Income Per & $(n=50)$ & 32.4 \\
\cline { 2 - 3 } Year (in USD) & $<5,000$ & 17.3 \\
\cline { 2 - 3 } & $5,000-10,000$ & 30.3 \\
\cline { 2 - 3 } & $>10,000$ & \\
\hline
\end{tabular}

Table 2

Travel Behavior Characteristics of Respondent

\begin{tabular}{|l|l|l|}
\hline Characteristic & Percentage \\
\hline Total Approximately Expenditure & $(n=50)$ in USD & \\
during Visit for Following Item: & $0-50$ & 7 \\
Transportation; Accommodation; & $50-500$ & 30.8 \\
\cline { 2 - 3 } Souvenirs; Food; Entertainment & $500-5,000$ & 40.2 \\
\cline { 2 - 3 } & $5,000-50,000$ & 22 \\
\hline \multirow{4}{*}{$\begin{array}{l}\text { Accompanying person during visit to } \\
\text { Bali }\end{array}$} & $(n=50)$ & 26 \\
\cline { 2 - 3 } & None (alone) & 26 \\
\cline { 2 - 3 } & Bestfriend & 28 \\
\cline { 2 - 3 } & Familly & 20 \\
\cline { 2 - 3 } & Group & 20 \\
\hline \multirow{4}{*}{$\begin{array}{l}\text { Source Information to choose Bali as } \\
\text { Tourist Destination for Holiday }\end{array}$} & (n=50) & 16.7 \\
\cline { 2 - 3 } & Travel Agency & 16 \\
\cline { 2 - 3 } & Family/ Friend & 28.3 \\
\cline { 2 - 3 } & Magazine/ Newspaper & \\
\hline
\end{tabular}




\begin{tabular}{|c|c|c|}
\hline & Word of Mouth & 5 \\
\hline & Books and Travel Guide & 8 \\
\hline & Fairs or Exhibition & 8 \\
\hline \multirow{6}{*}{ Main Type of Accommodation used } & $(n=50)$ & \\
\hline & Hotel/Motel/In/ Resort & 47.5 \\
\hline & Guesthouse & 25 \\
\hline & $\begin{array}{l}\text { Homes of Friends or } \\
\text { Relatives }\end{array}$ & 18.5 \\
\hline & Camping & 7 \\
\hline & Second home & 2 \\
\hline \multirow{5}{*}{ Length of Stay in Bali } & $(n=50)$ & \\
\hline & 7 days or less & 41 \\
\hline & 8 - 14 days & 24 \\
\hline & 14 - 30 days & 22 \\
\hline & more than 1 month & 13 \\
\hline \multirow{8}{*}{$\begin{array}{l}\text { Main method of Transport used to } \\
\text { Travel to this area }\end{array}$} & $(n=50)$ & \\
\hline & Bus & 15 \\
\hline & Coach Tour & 27.8 \\
\hline & Car & 15 \\
\hline & Taxi & 20 \\
\hline & Motorcycle & 15.8 \\
\hline & Bicycle & 5 \\
\hline & Walk/ hiked & 1.4 \\
\hline \multirow{5}{*}{ Number of time to visit Bali } & $(n=50)$ & \\
\hline & None & 17 \\
\hline & 1 time & 36.5 \\
\hline & 2 - 3 Times & 41.2 \\
\hline & More than 3 times & 5.3 \\
\hline \multirow{4}{*}{$\begin{array}{l}\text { Travel decision-making time to stay } \\
\text { at Bali as tourist destination }\end{array}$} & $(n=50)$ & \\
\hline & Less than a month & 23.5 \\
\hline & $1-3$ months ago & 52 \\
\hline & More than 3 months ago & 24.5 \\
\hline
\end{tabular}


Table 3

\section{The Total Average of Data Analysis}

\begin{tabular}{|c|c|c|}
\hline \multicolumn{3}{|c|}{ Event Tourism $(\mathrm{X})$} \\
\hline No & $\begin{array}{l}\text { Plan to Visit The Destination due to Event } \\
\text { Tourism in Bali (a) }\end{array}$ & $\begin{array}{l}\text { The Average Total Score of } 50 \\
\text { Respondents }\end{array}$ \\
\hline $\mathrm{X} 1$ & Nyepi (Silent Day) & 4.24 \\
\hline $\mathrm{X} 2$ & Parade of Ogoh - Ogoh & 4.36 \\
\hline $\mathrm{X} 3$ & $\begin{array}{l}\text { Omed - Omedan Festival (festival of splashes \& } \\
\text { smooches in Sesetan's Village) }\end{array}$ & 3.36 \\
\hline $\mathrm{X} 4$ & Sanur Village Festival & 3.42 \\
\hline $\mathrm{X} 5$ & Kuta Karnival & 4.06 \\
\hline X6 & Nusa Dua Festival & 3.7 \\
\hline $\mathrm{X} 7$ & Bali Arts Festival & 3.84 \\
\hline $\mathrm{X} 8$ & $\begin{array}{l}\text { Bali Spirit Festival (Annual Festival of Yoga; Dance; } \\
\& \text { Music in Bali) }\end{array}$ & 2.78 \\
\hline $\mathrm{X} 9$ & Bali Kites Festival & 3.54 \\
\hline
\end{tabular}

Tourist's Motivation Characteristics (Y1)

\begin{tabular}{|c|c|c|}
\hline \multirow[t]{2}{*}{ No } & Statements & \multirow[t]{2}{*}{$\begin{array}{l}\text { The Average Total Score of } \mathbf{5 0} \\
\text { Respondents }\end{array}$} \\
\hline & Main Purpose of Visiting Bali $(a)$ : & \\
\hline Y1.1 & Relax Mentally & 3.7 \\
\hline Y1.2 & Discover New Place \& Things & 3.52 \\
\hline Y1.3 & Discover "my self" (identity) & 3.36 \\
\hline Y1.4 & Avoid the Hustle \& Bustle of Daily Life & 4.1 \\
\hline Y1.5 & Relax Physically & 3.86 \\
\hline Y1.6 & Enhance my Experience & 4.1 \\
\hline Y1.7 & $\begin{array}{l}\text { Attending a conference, congress, seminar, and other } \\
\text { forms of educations }\end{array}$ & 3.62 \\
\hline Y1.8 & Visiting Event Tourism in the destination & 4.08 \\
\hline No & $\begin{array}{l}\text { The Main Characteristic of the area that made you } \\
\text { visiting Bali }(b) \text { : }\end{array}$ & $\begin{array}{l}\text { The Average Total Score of } \mathbf{5 0} \\
\text { Respondents }\end{array}$ \\
\hline Y1.9 & Accessibility & 3.86 \\
\hline Y1.10 & Historic interest & 4.24 \\
\hline Y1.11 & Peace and quiet atmosphere & 4.14 \\
\hline
\end{tabular}




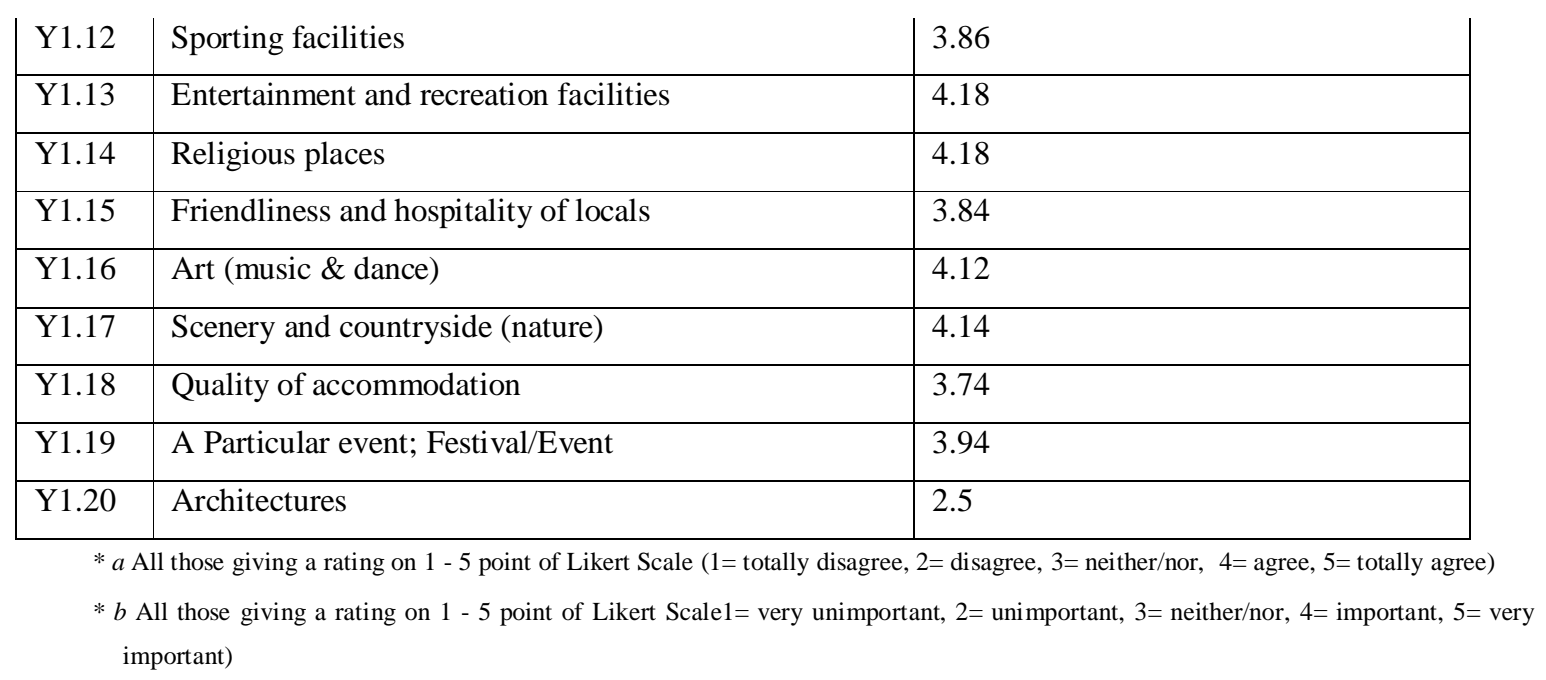

\section{Tourist Destination Image (Y2)}

\begin{tabular}{|c|c|c|}
\hline No & $\begin{array}{l}\text { The Perception/ Image of Bali by held an Event } \\
\text { Tourism as a Tourist Attraction }(a \& b)\end{array}$ & $\begin{array}{l}\text { The Average Total Score of } \mathbf{5 0} \\
\text { Respondents }\end{array}$ \\
\hline Y2.1 & Offers good value for the money & 3.36 \\
\hline Y2.2 & Has convenient public and private transport & 4.08 \\
\hline Y2.3 & Has rich cultural heritage & 3.84 \\
\hline Y2.4 & Has good quality service & 3.56 \\
\hline Y2.5 & $\begin{array}{l}\text { Offers a good opportunity to increase my knowledge } \\
\text { about different culture }\end{array}$ & 3.12 \\
\hline Y2.6 & Has good security system during the event & 3.54 \\
\hline Y2.7 & Create a memorable experience & 3.86 \\
\hline Y2.8 & Informative & 2.7 \\
\hline Y2.9 & Has friendly local people & 4.12 \\
\hline $\mathrm{Y} 2.10$ & $\begin{array}{l}\text { My overall image of Bali with the Event Tourism } \\
\text { attraction is positive. }\end{array}$ & 4.24 \\
\hline No & $\begin{array}{l}\text { Previous Experiene by Visiting Event Tourism in } \\
\text { Bali }\end{array}$ & $\begin{array}{l}\text { The Average Total Score of } \mathbf{5 0} \\
\text { Respondents }\end{array}$ \\
\hline Y2.11 & Choose Bali as your next travel destination & 3.8 \\
\hline $\mathrm{Y} 2.12$ & $\begin{array}{l}\text { Has plan to travel to Bali in the next } 5 \text { years for } \\
\text { vacation purpose }\end{array}$ & 2.72 \\
\hline $\mathrm{Y} 2.13$ & $\begin{array}{l}\text { Has plan to travel to Bali for visiting the Event } \\
\text { Tourism purposes }\end{array}$ & 3.54 \\
\hline $\mathrm{Y} 2.14$ & Visiting Event Tourism in Bali is expensive & 3.66 \\
\hline
\end{tabular}


$* a$ and $b$ All those giving a rating on $1-5$ point of Likert Scale $(1=$ totally disagree, $2=$ disagree, $3=$ neither/nor, $4=$ agree, $5=$ totally agree)

Table 4

Chi-Square Analysis with SPSS Version 23

Chi-Square Tests - Event Tourism $(X)$ towards Tourist Motivation (Y1.1 - Y1.8)

\begin{tabular}{|l|l|l|l|}
\hline & Value & df & $\begin{array}{l}\text { Asymptotic } \\
\text { Significance (2- } \\
\text { sided) }\end{array}$ \\
\hline Pearson Chi-Square & $130.249^{\mathrm{a}}$ & 20 & .000 \\
Likelihood Ratio & 44.305 & 20 & .001 \\
Linear-by-Linear Association & 21.768 & 1 & .000 \\
N of Valid Cases & 50 & & \\
\hline
\end{tabular}

a. 26 cells (86.7\%) have expected count less than 5. The minimum expected count is .02 .

Symmetric Measures

\begin{tabular}{|ll|l|l|}
\hline & & Approximate \\
& & Value & Significance \\
\hline Nominal by Nominal & Phi & 1.614 & .000 \\
& Cramer's V & .807 & .000 \\
N of Valid Cases & & 50 & \\
\hline
\end{tabular}

Chi-Square Tests - Event Tourism $(X)$ towards Tourist Motivation (Y1.9 - Y1.20)

\begin{tabular}{|l|l|l|l|}
\hline & Value & df & $\begin{array}{l}\text { Asymptotic } \\
\text { Significance (2- } \\
\text { sided) }\end{array}$ \\
\hline $\begin{array}{l}\text { Pearson Chi-Square } \\
\text { Likelihood Ratio }\end{array}$ & $\begin{array}{l}108.865^{\mathrm{a}} \\
52.953\end{array}$ & $\begin{array}{l}.000 \\
20\end{array}$ & .000
\end{tabular}




\begin{tabular}{|l|l|l|l|} 
Linear-by-Linear Association & 21.354 & 1 & .000 \\
N of Valid Cases & 50 & & \\
\hline
\end{tabular}

a. 26 cells (86.7\%) have expected count less than 5. The minimum expected count is .02.

Symmetric Measures

\begin{tabular}{|c|c|c|c|}
\hline & & Value & $\begin{array}{l}\text { Approximate } \\
\text { Significance }\end{array}$ \\
\hline \multirow[t]{2}{*}{ Nominal by Nominal } & Phi & 1.476 & .000 \\
\hline & Cramer's V & .738 & .000 \\
\hline $\mathrm{N}$ of Valid Cases & & 50 & \\
\hline
\end{tabular}

Chi-Square Tests - Event Tourism (X) towards Tourist Destination Image (Y2)

\begin{tabular}{|l|l|l|l|}
\hline & & & $\begin{array}{l}\text { Asymptotic } \\
\text { Significance (2- } \\
\text { sided) }\end{array}$ \\
& Value & df & .000 \\
Pearson Chi-Square & $103.352^{\mathrm{a}}$ & 15 & .000 \\
Likelihood Ratio & 45.119 & 15 & .000 \\
Linear-by-Linear Association & 21.768 & 1 & 50
\end{tabular}

a. 20 cells (83.3\%) have expected count less than 5. The minimum expected count is .02.

Symmetric Measures

\begin{tabular}{|ll|l|l|}
\hline \multicolumn{1}{|l|}{} & & Value & Approximate Significance \\
\hline Nominal by Nominal & Phi & 1.438 & .000 \\
& Cramer's V & .830 & .000 \\
N of Valid Cases & & 50 & \\
\hline
\end{tabular}

\section{Discussion}

The instrument used in this study was a questionnaire, which the research data will be analyzed by using the tools of statistical calculations or tests, before interpreting the data obtained. Table 1 discussed the socio-economic and 
demographic character of respondents based on nationality, gender, educational background, employment level, marital status, and total revenue per year (in USD). Approximately $30.9 \%$ of the tourists came from several regions in Indonesia, while $26.8 \%$ of respondents were from Australia, 15.7\% from Asia, $14.4 \%$ from Europe, and amounted to $12.2 \%$ came from the state of America. 50 respondents who answered the question were mostly female (52.1\%) and $47.9 \%$ of male. As for the educational background of the respondents at the time of data collection was largely under-graduated with a percentage around $49.6 \%$, followed by a post-graduated around $30 \%$, and high school and below around $20.4 \%$. For employment level, as employees amounted to $39.7 \%$, managers and directors amounted to $34.7 \%$, and supervisors amounted to $25.6 \%$. More than $50 \%$ of respondents was still single and amounted to $42.3 \%$ were married, with the average of revenue per year was over 5,000 USD which amounted to $52.4 \%$.

The studies on the characteristics of tourists was not only limited to the socio-demographic but also tourist behavior which in this case as evaluated based on the total expense of them when visiting Bali as a tourist destination; who they invite to travel, the source of information in determining Bali as a tourist destination; length of stay; the mode of transportation used in Bali; how many times visiting Bali; and a long period of time in determining Bali as a tourist destination. Based on data collection toward 50 respondents, it was known that the total expense for visiting Bali ranged from 500- 5,000 USD with a percentage of $40.2 \%$. The average of their vacation with family with a total percentage of $28 \%$ followed by close friends and alone vacation by $26 \%$ in each and with group around $20 \%$. While resources in determining Bali as a destination largely derived from the internet considering the current era of globalization or a borderless world amounted to $28.3 \%$. Proceed with the indicator of transport modes, most of the respondents use tour buses because public transport does not run as good as in developed countries, and by $47.5 \%$ of respondents chose to stay at a hotel or resort than camping or staying with friends or relatives. And most of the tourists had been to Bali more than once with a percentage of $41.2 \%$. This shows that the island of Bali remains a favorite destination for domestic and foreign tourists. 
Collecting data was continued by dividing the instrument into three parts, namely the independent variable such as Event Tourism (X); the dependent variable 1 such as Tourist Motivation (Y1); and the dependent variable 2 of the Tourist Destination Image (Y2). The results were Chi-Square test on the relationship between tourism event with tourist motivation 1 (Y1.1 - Y1.8), Pearson Chi-Square line indicated data $\mathrm{df}=20$ and $\mathrm{p}$-value $=0.000<0.05$ or Ho was rejected, while table symmetric measure show contingency coefficient of 1.614 which indicates the level of the relationship of event tourism and tourist motivation 1 (Y1.1 - Y1.8). Furthermore, the results of Chi-Square Test in determining the relationship between event tourism and the tourist motivation (Y1.9 - Y1.20) was a line of Pearson Chi-Square which showed the data $\mathrm{df}=20$ and $\mathrm{p}$-value $=0.000<0.05$ or Ho was rejected, and table symmetric measure show contingency coefficient of 1.476 which indicates the level of the relationship of event tourism and tourist motivation 2 (Y1.9 - Y1.20). Thus there is a positive relationship between event tourism with the travel motivation which in this case is evaluated based on the indicators relax mentally and physically; discover new place and things; discover "myself" (identity); avoid the hustle and bustle of daily life; enhance my experience; attending MICE events; the desire to visit the historical and religious places, enjoy the entertainment, until come specifically to watch the ongoing event tourism. It can be seen that visiting the event tourism; geting more experiences, and taking a break from the routine become big motivation to visit Bali. Meanwhile, event tourism which according to the respondents are required to be witnessed or enjoyed was in Silent Day, Ogoh Ogoh Parade, Kuta Karnival, and Bali Art Festival. Event Tourism is more representative character of Bali as the island with attractiveness especially culture and shaping its own image as a unique tourist destination.

The results of Chi-Square Test in determining the relationship between event tourism and tourist destination image shows Pearson Chi-Square lines indicated the data $\mathrm{df}=15$ and $\mathrm{p}$-value $=0.000<0.05$ or Ho rejected, and table symmetric measure indicates contingency coefficient of 1.438 which indicates the level the relationship of tourism events and tourist destination image. The tourists' perception of the image of Bali by organizing Event Tourism is a very 
friendly community, creating a different experience; modes of transportation are quite comfortable, and rich in cultural heritage. Most images are created through tourist attraction with Event Tourism was positive by travelers. Similar to the theory that stated the destination compete to have competitiveness in order to remain a favorite tourist destination. Creating a positive image of the destination, also positively correlated to the arrival of tourists.

This study discussed how Event Tourism was able to be a positive stimulus in attracting tourist arrivals to tourist destinations. The event became an important element in the system of tourism, even able to give value to the destination when vacancy occurs in the low seasons (Getz and Page, 2015; Leiper 1990). Through the analysis of the Chi-Square will be known a model that holds the event tourism as one promotion strategy of tourism destination contributed positively to the tourist motivation to come to visit Bali. Chen (2011) conducted a study on local perceptions of the annual event tourism in Macao and by using cluster analysis found a new factor of personal gain which some communities are more focused on the experiences they have gained rather than good or bad effects resulting from the implementation of the event. For tourists, the experience is an important point in the travel and event tourism which is unique from many destinations to be one way to create a unique experience. People who are motivated because the event tourism indicates that the destination marketing activity through tourism event gives significant influence on tourist loyalty in the destination (Truong and Foster, 2006; Lai and Vinh, 2013; Kotle, et.al., 2010; Moesly et.al., 2011). Event no longer just considered as promotional tools, but an important component in the management and destination development to a higher level.

It is known that the implementation of Event Tourism is one of the tourism destination promotion strategies that contributed positively to the motivation of tourists to come to visit Bali. That motivation is also guided by a variety of different purposes such as business activities, a time for relaxation as well as seeking a different experience to enjoy the special events that are taking place. Bali local government must continue to improve creativity in encouraging the growth of Event Tourism for the realization of destination image which safe, 
peaceful, and superior because of its cultural attractions, natural or man-made art. The local government is also expected to pay particular attention to the potential of this special interest market. In the future, the review of Event Tourism is expecting to be strengthened by adding more variables that are relevant to issues of tourism nowadays.

\section{References}

Arcana, Komang Trisna Pratiwi. 2014. "The Implementation of Sustainable Event Management into MICE Management at BTDC, Nusa Dua Bali". Thesis. France: University of Angers.

Baloglu, S. and McCleary, K. 1999. "A Model of Destination Image Formation”. Annals of $\quad$ Tourism Research, 26 (4), 869-97.

Bond, Howard. 2008. “Estimating The Economic Benefits of Event Tourism, A Review of Research Methodologies". (www.impacts08.net, accessed 18 March 2016).

Celik, Serkan, and Mehmet Yauz Cetinkaya. 2013. “Festival in Event Tourism: The Case of International Izmir Art Festival". International Journal of Contemporary Economics and Administrative Sciences. 3 (1). 1-21.

C. Chen Sandy. 2011. “Ressidents' Perceptions of The Impact of Major Annual Tourism Events in Macao: Cluster Analysis". Journal of Convention and Event Tourism. 12 (2011) 106 128.

Chen, Yu-Fen and Huai-En Mo. 2014. “A Survey of Push and Pull Motivations of Green Event Tourists". International Journal of Information and Education Technology. 4 (3). 260-_...263.

Cooper Chris 2012. "Essentials of Tourism”. Edinburgh: Pearson Education Limited. 
Dinas Pariwisata Provinsi Bali. 2005. “2004 Bali Tourism Statistics”. Denpasar: Dinas Pariwisata Provinsi Bali.

Getz, Donald. 2007. "Event Tourism: Definition, Evolution, And Research". Tourism Management, Tourism Management 29 (2008), $403-428$.

Getz, Donald, and Stephen J. Page. 2015. “Progress and Prospects for Event Tourism Research". 52(2016), 593-631.

Hara, Tadayuki. 2008. “Quantitative Tourism Industry Analysis Introduction to Input-Output, Social Accounting Matrix Modelling and Tourism Satellite Accounts". Oxford: Butterworth - Heinemann.

Jennings, Gayle. 2001. “Tourism Research”. Sydney: John Wiley \& Sons.

Kadir 2015. “Statistika Terapan, Konsep, Contoh, dan Analisis Data dengan Program SPSS/ Lisrel dalam Penelitian". Jakarta: PT. RajaGrafindo Persada.

Kartajaya, Hermawan., dan Sapta Nirwandar. 2013. “Tourism Marketing 3.0, Turning Tourist to Advocate". Jakarta: PT. Gramedia Pustaka Utama.

Kotler, Bowen, dan Makens. 2014. "Marketing for Hospitality and Tourism".

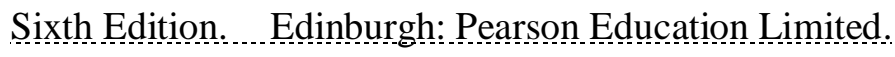

Lai, W.H. and Vinh, N.Q. 2013. "How Promotional Activities and Evaluative Factors Affect Destination Loyalty: Evidence from International Tourists of Vietnam". International Journal of Marketing Studies 5 (1) . 70 - 85. 
LeBlanc, Gaston \& Nguyen, Nha. 1996. "Cues Used by Customers Evaluating Corporate Image in Service Firms". International Journal of Service Industry Management, Vol.7, No.2, .....pp. 44-56.

Moesly, Matthew C; Xinran Lehto; Jonathon Day. 2011. "The Influence of The JazzFestival Experience on Bourist on Behavior". (http://scholarworks.umass.edu, accessed on $25 \quad$ February 2016).

Milman, A., \& Pizam, A. 1995. "The Role of Awareness and Familiarity with a Destination: The Central Florida Case". Journal of Travel Research, $33,21-35$.

Page, Stephen J., and Joanne Connell. 2009. "Tourism A Modern Synthesis". Third Edition. UK: $\quad$ South-Western Cengage Learning.

Pearce Philip L. 2005. "Tourist Behaviour-Themes and Conceptual Schemes": UK: Channel View Publications.

Purnamasari, Ni Putu Diah. 2014. “Upaya Pemerintah Bali dalam Mengembangkan Pariwisata Pasca Bom Bali I dan II'. eJournal. 2 (2). $351-362$.

Putri. Indah Sukmawati Manti. 2008. “Faktor - faktor yang Berhubungan dengan Perilaku Pencegahan DBD pada Murid Sekolah Dasar di Kota

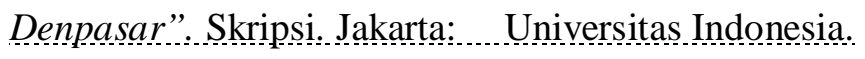

Ritchie, J.R. Brent.1997. “Beacons of Light in An Expanding Universe: An $\square$ Assessment OfThe State-Of-The-Art in Tourism Marketing / Marketing Research", Journal of Travel and Tourism Marketing, 5(4), 49. 84.

Sugiyono. 2014. "Statistika untuk Penelitian". Cetakan ke-25. Bandung: Alfabeta. 
Tribe, John. 2010. "Strategy for Tourism". Oxford: Goodfellow Publishers Limited.

Truong, T.H. and King B. 2009. “An Evaluation of Satisfaction Levels among Chinese Tourists in Vietnam). International Journal of Tourism Research $11(6), 521-535$.

United Nation World Tourism Organization. 2016. "International Tourist Arrivals Up 4\% Reach a Record 1.2 Billion in 2015". Press Release. (www.unwto.org, accessed on 20 January 2016).

United Nation World Tourism Organization. 2016. "World Tourism Barometer: 2015 International Tourism Results and Prospects for 2016"..(www.unwto.org, accessed on 20 _ January 2016).

Vinh, Nguyen Quang. 2013. “Destination Culture and Its Influence on Tourist Motivation and Tourist Satisfaction on Homestay Visit”. Journal of The Faculty of Economics and Administrative Sciences. 3(2), 1999-222.

Yingzhi, Guo, Li Xiaoming, and Daizy Liu. 2013. "A Case Study of Tourists' Perceived Motivation and Impacts of Sport Tourism Event". Journal of Tourism and Hospitality Management. 1 (2), 89-94. 